\title{
Evaluation of Renal Adverse Effects of Combination Anti-retroviral Therapy including Tenofovir in HIV-infected Patients
}

\author{
Hiroyuki Tanaka ${ }^{1,4}$, Mariko Arai ${ }^{2}$, Yoshinori Tomoda ${ }^{1}$, Tatsuhiko Wada ${ }^{3}$, Kazuo Yago $^{1}$, Mitsutoshi Satoh ${ }^{4}$ \\ ${ }^{1}$ Department of Pharmacy, Kitasato University Hospital, 1-15-1 Kitasato, Minamiku, Sagamihara, \\ Kanagawa, JAPAN; ${ }^{2}$ Department of Pharmacy, Kitasato University East Hospital, 2-2-1 Asamizodai, \\ Minamiku, Sagamihara, Kanagawa, JAPAN; ${ }^{3}$ Department of Rheumatology and Infectious Diseases, \\ Kitasato University School of Medicine, 1-15-1 Kitasato, Minamiku, Sagamihara, Kanagawa, JAPAN; \\ ${ }^{4}$ Department of Toxicology and Pharmacology, Faculty of Pharmaceutical Sciences, Toho University, \\ 2-2-1 Miyama, Funabashi, Chiba, JAPAN
}

Received, January 18, 2013; Revised, April 19, 2013; Accepted, May $6^{\text {th }}, 2013$; Published, May $7^{\text {th }}, 2013$.

ABSTRACT - Purpose. In order to maintain plasma HIV-RNA concentration below the detection limit in HIV-infected patients, combination anti-retroviral therapy (cART) are used. Although the nucleoside/nucleotide reverse transcriptase inhibitor, tenofovir disoproxil fumarate (TDF) is a first-line drug commonly used, it is associated with renal dysfunction. Nevertheless, only few clinical studies have focused on TDF in combination with new anti-HIV drugs, including the protease inhibitor (PI) darunavir (DRV), or the integrase strand transfer inhibitor (INSTI) raltegravir (RAL). Here we report the influence of such cART involving TDF on renal function. Methods. We retrospectively investigated 68 patients under cART that included TDF between November 2004 and May 2012. We used hospital records to establish each patient's background and characteristics, CD4 cell count, plasma HIV-RNA concentration, drug combinations, renal function, and anti-retrovial therapy history. Results. In all patients who had received cART, the plasma HIV-RNA concentration had fallen to less than 40 copies/mL by week 24 after the start of the therapy, and an increase in the CD4 cell count was observed. For each drug used in combination with TDF, the plasma HIV-RNA concentration and CD4 cell count showed a similar trend. After week 12, the estimated glomerular filtration rate (eGFR) had significantly decreased in all patients. The eGFR was significantly lower in those received PI on week 24 and in those received INSTI on week 12 . The eGFR was significantly reduced in PI group who received atazanavir + ritonavir (ATV/RTV) on week 60. The eGFR in the DRV/RTV group tended to decrease. The eGFR in the PI and ATV/RTV group was significantly lower than in the efavirenz (EFV) group on week 96. Conclusion. It selecting drugs to include in combination therapy of HIV-infected patients, consideration should be given to the risk of renal dysfunction. There is a need to monitor renal function when TDF is combined with ATV/RTV, DRV/RTV or RAL.

This article is open to POST-PUBLICATION REVIEW. Registered readers (see "For Readers") may comment by clicking on ABSTRACT on the issue's contents page.

\section{INTRODUCTION}

Patients with HIV infection are treated with combination anti-retroviral therapy (cART) using more than three drugs in order to maintain the plasma HIV-RNA concentration below the detection limit. In treating naïve patients, cART usually consists of two nucleoside/nucleotide reverse transcriptase inhibitors (NRTIs) plus a non-nucleoside reverse transcriptase inhibitor (NNRTI), a ritonavir (RTV)-boosted protease inhibitor (PI), or an integrase strand transfer inhibitor (INSTI).

Corresponding Author: Dr. Mitsutoshi Satoh, Department of Toxicology and Pharmacology, Faculty of Pharmaceutical Sciences, Toho University, 2-2-1 Miyama, Funabashi, Chiba, JAPAN. E-mail: satoh@phar.toho-u.ac.jp 
As a result of the development of anti-HIV drugs in recent years, HIV infection has become a chronic disease that is controllable by aggressive drug therapy (1). Although the prognosis of HIV-infected patients has been markedly improved as a result of such drug therapy, once cART has started, patients must continue taking several drugs periodically for a long time, and therefore various adverse effects induced by anti-HIV drugs may occur. Renal dysfunction is one of the more serious of these adverse effects.

Tenofovir disoproxil fumarate (TDF) is a NRTI recommended in international treatment guidelines for initial treatment of HIV-infected patients. The Department of Health and Human Services (DHHS) guidelines recommend a fixed-dose combination tablet of TDF plus emtricitanine (FTC), as the preferred NRTIs for initial therapy. As TDF is relatively safe in comparison to other NRTIs, it is used worldwide. However, its adverse effects include renal tubule damage, Fanconi syndrome and nephrogenic diabetes insipidus $(2,3)$. In a recent study of renal dysfunction induced by TDF, Gallant et al. compared the estimated glomerular filtration rate (eGFR) of patients medicated with TDF and that of patients medicated with other NRTI for 24 months, and found no significant differences in the decrease of the eGFR (4). On the other hand, Horberg et al. have reported that the GFR in TDF-medicated patients was significantly lower than that in other NRTI-medicated patients (5). Moreover, a high serum creatinine value, low body weight, high age, low CD4 cell count, combined use of medicines inducing renal dysfunction, high blood pressure and diabetes have been reported as risk factors for renal dysfunction in patients receiving TDF medication $(6,7)$. Some reports have suggested that the risk of renal dysfunction in patients receiving combination therapy with TDF and PIs is higher than that for combination therapy with TDF and NNRTI $(4,8)$.

In the DHHS guidelines, a regimen that combines TDF with a novel PI, darunavir (DRV), or an INSTI, raltegravir (RAL), is recommended for initial treatment of HIV infection. However, few previous studies have investigated regimens in which TDF is combined with DRV or RAL. Therefore, we evaluated the impact of cART including TDF in combination with NNRTI, PI and INSTI regimens.

\section{METHODS}

Patient characteristics, parameters and prescription information

We retrospectively evaluated $68 \mathrm{HIV}$-infected patients who had received cART including TDF at Kitasato University Hospital between November 2004 and May 2012. The patients' backgrounds and characteristics were established from the hospital medical records, and the data included the CD4 cell count, the plasma HIV-RNA concentration, anti-retroviral drug combination, renal function, and anti-retroviral therapy history. Moreover, the change in the eGFR after the start of cART including TDF was compared with that for each drug at weeks $4,12,24,36$, $48,60,72,84$ and 96. In addition, we examined any influence of the previous anti-retroviral therapy before cART including TDF.

\section{STATISTICAL ANALYSIS}

Numerical results were expressed as mean \pm S.D., and data were analyzed using Dunnett's test, Tukey-Kramer Multiple Comparison test and Welch's $t$ test. Differences at $P<0.05$ were considered to be statistically significant.

\section{ETHICS}

All the patients were surveyed after obtaining approval from the Institutional Review Board of Kitasato University Hospital (approval number; 10-117)

\section{RESULTS}

\section{Patient characteristics}

The patients' characteristics are shown in Table 1. Among 69 patients who received cART including TDF, one woman who was found to be pregnant was excluded, leaving a 
total of 68 studied patients.

Among the patients who were administered TDF, 17 patients received TDF+NNRTI, efavirenz (EFV), 38 received TDF+PI (atazanavir+RTV (ATV/RTV) : 16 cases, DRV/RTV : 9 cases, fosamprenavir+RTV (FPV/RTV) : 5 cases, lopinavir+RTV (LPV/RTV) : 8 cases), and 13 received TDF+INSTI, RAL. A small dose of RTV was added as a booster in order to raise the blood level of the PI in all patients who received it. The NRTI used in combination with TDF in cART was either FTC or lamivudine (3TC) (Table 1).

Effect of cART on plasma HIV-RNA concentration and CD4 cell count

The time courses of the plasma HIV-RNA concentration and CD4 cell count in all patients from the initiation of cART including TDF are shown in Figure 1A. In almost all cases, the plasma HIV-RNA concentration had fallen to less than 40 copies $/ \mathrm{mL}$ by week 24 after the start of medication, and an increase in the CD4 cell count was observed. A similar tendency was also evident in patients receiving each of the drugs that were used in combination with TDF (Figure 1B and C).

\section{Influences of cART on renal function}

The time courses of the eGFR in all patients who received cART including TDF are shown in Figure 2A. The eGFR decreased in week 12 after the start of cART, and then tended to decrease gradually thereafter. eGFR after week 12 was significantly lower than that upon initiation of cART. In one patient medicated with TDF/FTC+ATV/RTV, the medication had to be changed at week 96 because of renal dysfunction (an eGFR decline of more than $30 \mathrm{~mL} / \mathrm{min} / 1.73 \mathrm{~m}^{2}$ and an increase of $\beta_{2}$-microglobulin in urine from the start of medication). The time courses of the eGFR in the patients who received TDF and combination drugs (NNRTI, PI or INSTI) are shown in Figure 2B-D. The eGFR in the PI group after week 24 and in the INSTI group after week 12 was significantly lower than that at the time of cART initiation. Moreover, the time courses of the eGFR in the patients receiving TDF in combination with PI (ATV/RTV, DRV/RTV, FPV/RTV and LPV/RTV) are shown in Figure 2E-H.

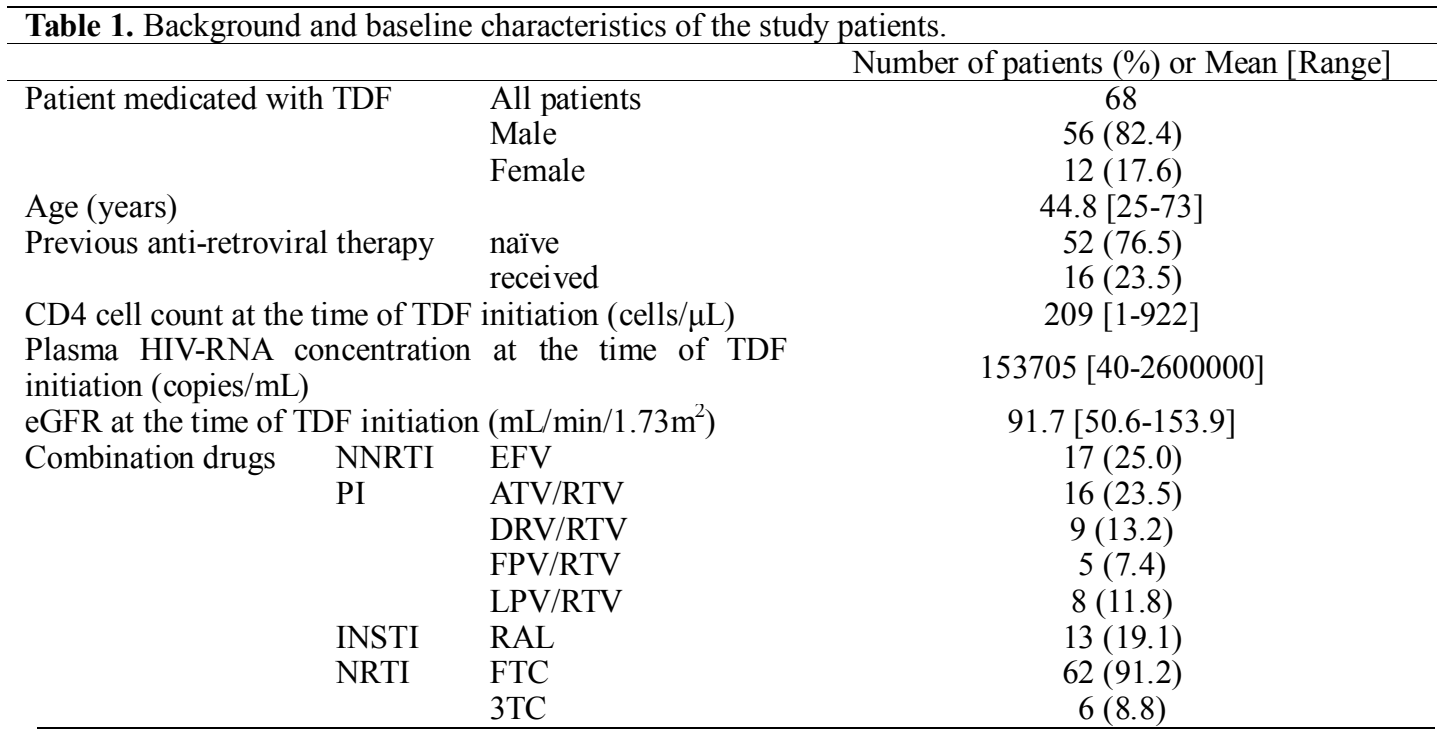

TDF: tenofovir disoproxil fumarate, NNRTI: non-nucleoside reverse transcriptase inhibitor, NRTI: nucleoside/nucleotide reverse transcriptase inhibitor, PI: protease inhibitor, INSTI: integrase strand transfer inhibitor, EFV: efavirenz, ATV: atazanavir, DRV: darunavir, FPV: fosamprenavir, LPV: lopinavir, RTV: ritonavir, RAL: raltegravir, FTC: emtricitabine, 3TC: lamivudine, eGFR: estimated glomerular filtration rate 
A

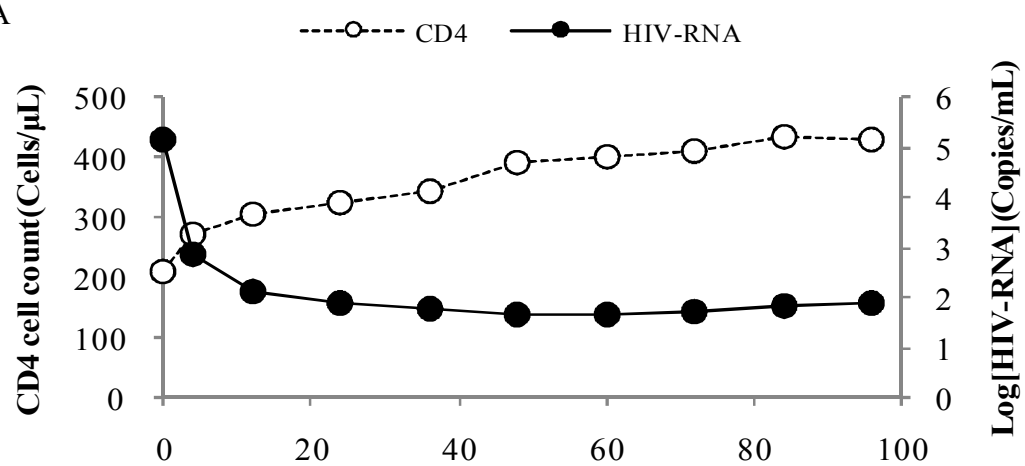

Time(Week)

B

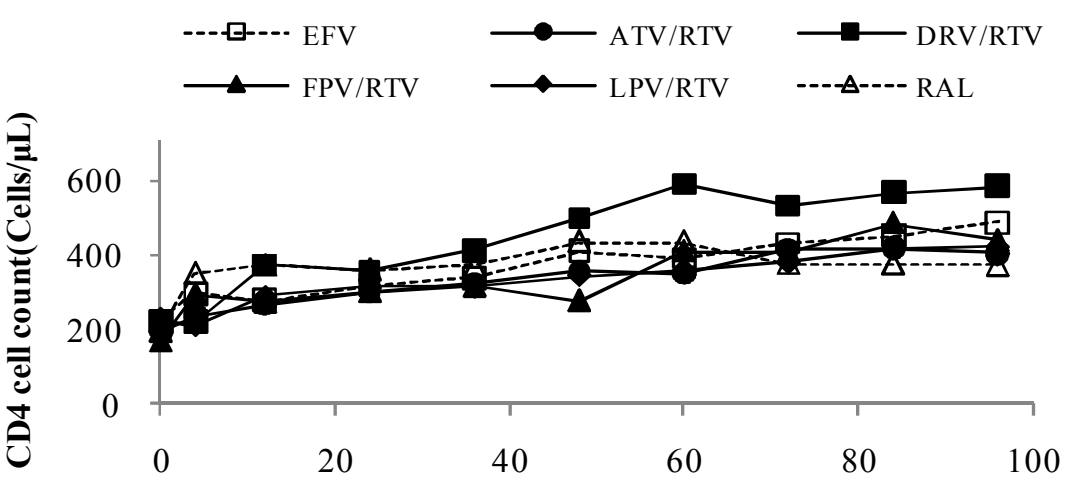

Time(Week)

C

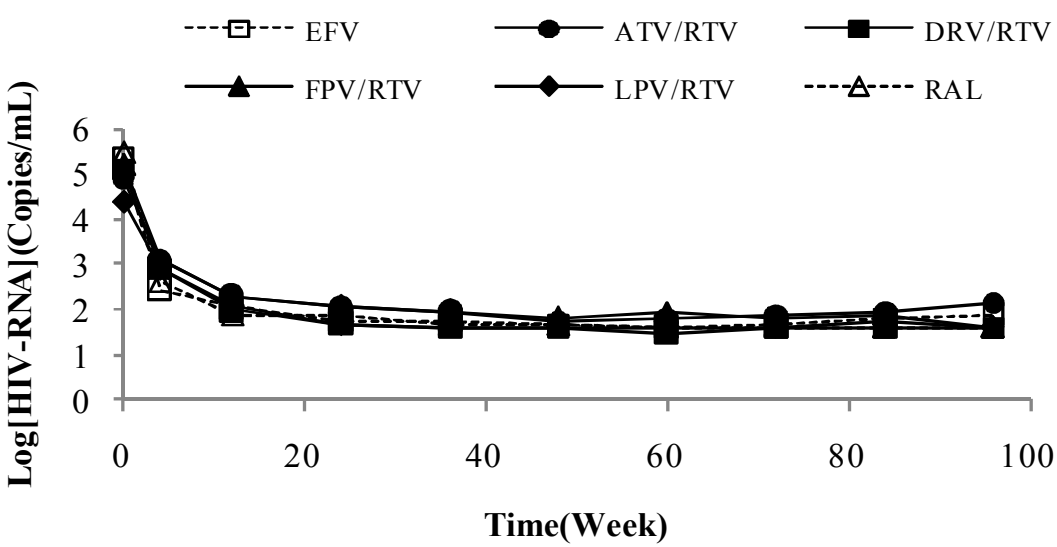

Figure 1. Time courses of therapeutic indicators.

A: CD4 cell count and plasma HIV-RNA concentration in all patients

B: CD4 cell count for each concomitant drug

C: Plasma HIV-RNA concentration for each concomitant drug 
The eGFR in the patients treated with the TDF and ATV/RTV combination after week 60 was lower than that at the start of cART. Although the eGFR in the patients treated with the TDF and DRV/RTV combination was not significantly different from that at the start of CART, it tended to be low.
A

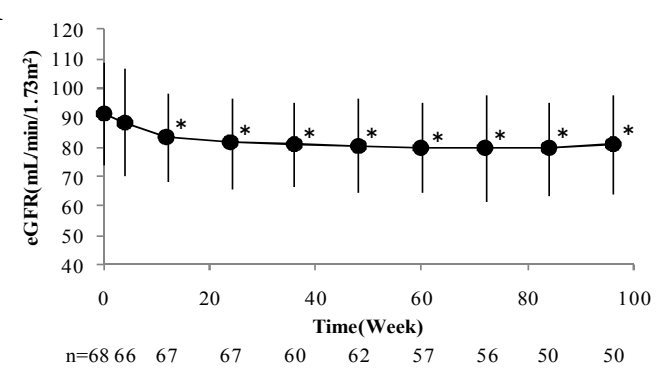

C

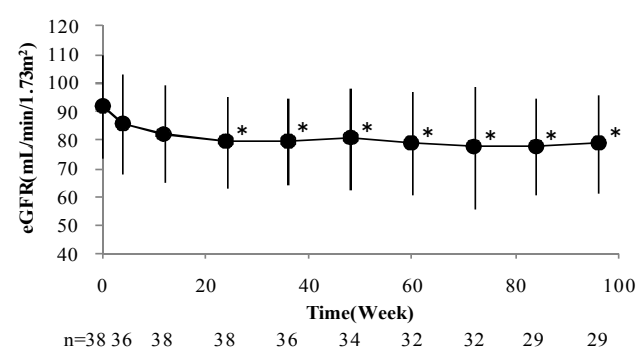

$\mathrm{E}$

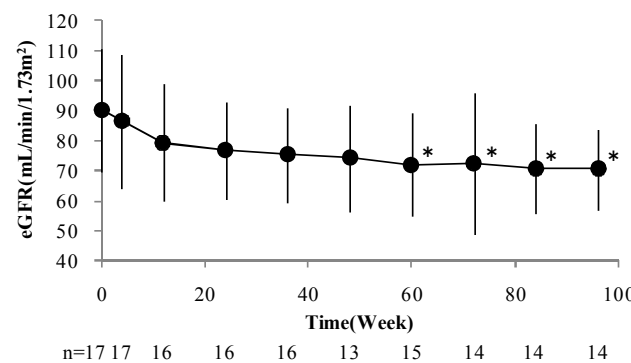

G

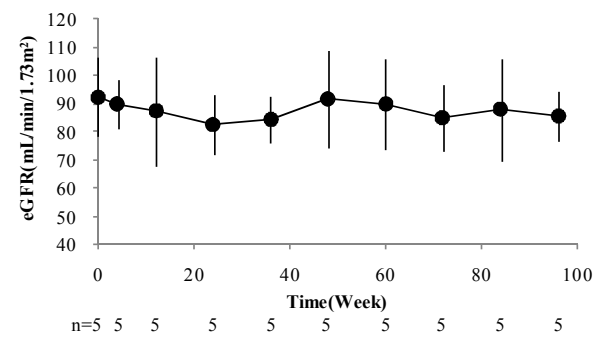

B

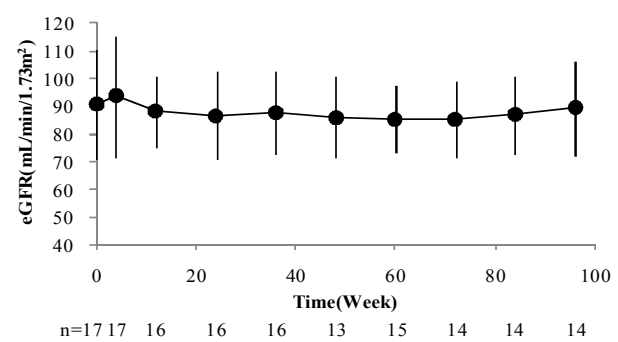

D

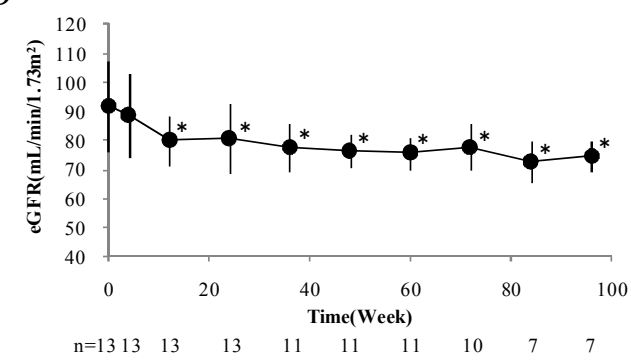

$\mathrm{F}$

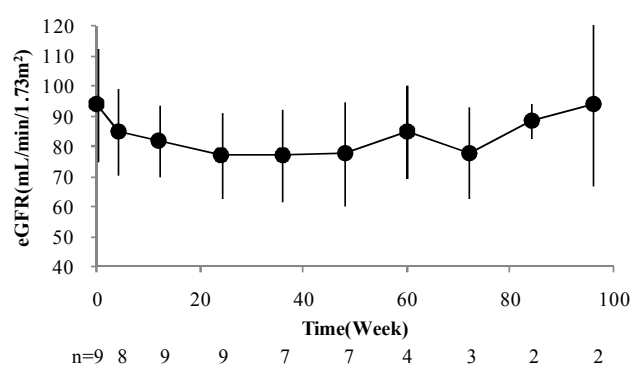

$\mathrm{H}$

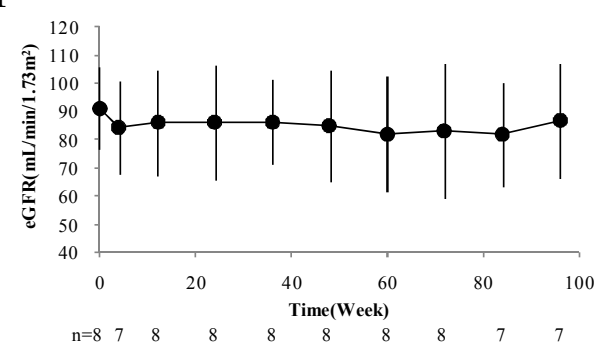

Figure 2. Time course of eGFR in all patients (A), patients who received NNRTI (EFV) (B), PI(C), INSTI (RAL) (D), ATV/RTV (E), DRV/RTV (F), FPV/RTV (G) and LPV/RTV (H) combination therapy mean \pm S.D. Dunnett's test $\quad *: P<0.05$ each follow-up point vs 0 week 


\begin{tabular}{|c|c|c|c|c|c|c|c|c|c|}
\hline & Week 4 & Week 12 & Week 24 & Week 36 & Week 48 & Week 60 & Week 72 & Week 84 & Week 96 \\
\hline $\begin{array}{l}\text { NNRTI (EFV) } \\
\text { (n) }\end{array}$ & $\begin{array}{c}2.8 \pm 11.0 \\
(17)\end{array}$ & $\begin{array}{c}-3.0 \pm 12.8 \\
(16)\end{array}$ & $\begin{array}{c}-3.7 \pm 15.9 \\
(16)\end{array}$ & $\begin{array}{c}-5.2 \pm 13.0 \\
(13)\end{array}$ & $\begin{array}{c}-4.8 \pm 13.5 \\
(15)\end{array}$ & $\begin{array}{c}-5.0 \pm 15.4 \\
(14)\end{array}$ & $\begin{array}{c}-5.3 \pm 16.7 \\
(14)\end{array}$ & $\begin{array}{c}-3.7 \pm 14.9 \\
(14)\end{array}$ & $\begin{array}{c}-1.2 \pm 14.9 \\
(14)\end{array}$ \\
\hline $\begin{array}{l}\text { PI } \\
\text { (n) }\end{array}$ & $\begin{array}{c}-4.2 \pm 13.0 \\
(36)\end{array}$ & $\begin{array}{c}-9.7 \pm 10.4 \\
(38)\end{array}$ & $\begin{array}{c}-12.5 \pm 13.4 \\
(38)\end{array}$ & $\begin{array}{c}-12.6 \pm 12.4 \\
(36)\end{array}$ & $\begin{array}{c}-11.8 \pm 15.7 \\
(34)\end{array}$ & $\begin{array}{c}-14.1 \pm 15.0 \\
(32)\end{array}$ & $\begin{array}{c}-14.6 \pm 18.8 \\
(32)\end{array}$ & $\begin{array}{c}-16.9 \pm 18.7 \\
(29)\end{array}$ & $\begin{array}{c}-15.1 \pm 17.1^{\mathrm{a}} \\
(29)\end{array}$ \\
\hline $\begin{array}{l}\text { ATV/RTV } \\
\text { (n) }\end{array}$ & $\begin{array}{c}-2.5 \pm 9.3 \\
(16)\end{array}$ & $\begin{array}{c}-10.8 \pm 8.5 \\
(16)\end{array}$ & $\begin{array}{c}-13.6 \pm 9.0 \\
(16)\end{array}$ & $\begin{array}{c}-14.9 \pm 10.6 \\
(16)\end{array}$ & $\begin{array}{c}-16.1 \pm 9.8 \\
(16)\end{array}$ & $\begin{array}{c}-19.2 \pm 10.6 \\
(15)\end{array}$ & $\begin{array}{c}-17.9 \pm 18.0 \\
(16)\end{array}$ & $\begin{array}{c}-22.2 \pm 11.7 \\
(15)\end{array}$ & $\begin{array}{c}-20.8 \pm 12.7^{b} \\
(15)\end{array}$ \\
\hline $\begin{array}{l}\text { DRV/RTV } \\
\text { (n) }\end{array}$ & $\begin{array}{c}-7.6 \pm 8.4 \\
(8)\end{array}$ & $\begin{array}{c}-12.3 \pm 10.5 \\
\text { (9) }\end{array}$ & $\begin{array}{c}-17.0 \pm 13.6 \\
(9)\end{array}$ & $\begin{array}{c}-16.8 \pm 11.7 \\
\text { (7) }\end{array}$ & $\begin{array}{c}-16.1 \pm 13.5 \\
\text { (7) }\end{array}$ & $\begin{array}{c}-14.6 \pm 15.4 \\
\text { (4) }\end{array}$ & $\begin{array}{c}-20.1 \pm 22.4 \\
\text { (3) }\end{array}$ & $\begin{array}{c}-16.6 \pm 33.0 \\
\text { (2) }\end{array}$ & $\begin{array}{c}-11.0 \pm 12.0 \\
\text { (2) }\end{array}$ \\
\hline $\begin{array}{l}\text { FPV/RTV } \\
\text { (n) }\end{array}$ & $\begin{array}{c}-2.8 \pm 11.5 \\
\text { (5) }\end{array}$ & $\begin{array}{c}-5.3 \pm 16.1 \\
(5)\end{array}$ & $\begin{array}{c}-10.8 \pm 18.2 \\
(5)\end{array}$ & $\begin{array}{c}-8.2 \pm 15.1 \\
(5)\end{array}$ & $\begin{array}{c}-0.9 \pm 25.0 \\
(5)\end{array}$ & $\begin{array}{c}-2.7 \pm 17.3 \\
(5)\end{array}$ & $\begin{array}{c}-7.5 \pm 16.0 \\
(5)\end{array}$ & $\begin{array}{c}-4.6 \pm 27.1 \\
(5)\end{array}$ & $\begin{array}{c}-6.7 \pm 20.5 \\
(5)\end{array}$ \\
\hline $\begin{array}{l}\text { LPV/RTV } \\
\text { (n) }\end{array}$ & $\begin{array}{c}-3.8 \pm 11.6 \\
(7)\end{array}$ & $\begin{array}{c}-5.4 \pm 9.8 \\
(8)\end{array}$ & $\begin{array}{c}-5.0 \pm 12.5 \\
(8)\end{array}$ & $\begin{array}{c}-5.0 \pm 7.1 \\
(8)\end{array}$ & $\begin{array}{c}-6.6 \pm 14.8 \\
(8)\end{array}$ & $\begin{array}{c}-9.2 \pm 16.1 \\
(8)\end{array}$ & $\begin{array}{c}-8.2 \pm 19.3 \\
(8)\end{array}$ & $\begin{array}{c}-12.3 \pm 15.7 \\
\text { (7) }\end{array}$ & $\begin{array}{c}-7.7 \pm 17.5 \\
\text { (7) }\end{array}$ \\
\hline $\begin{array}{l}\text { INSTI (RAL) } \\
\text { (n) }\end{array}$ & $\begin{array}{c}-3.2 \pm 10.0 \\
(13)\end{array}$ & $\begin{array}{c}-11.9 \pm 9.8 \\
(13)\end{array}$ & $\begin{array}{c}-11.2 \pm 17.3 \\
(13)\end{array}$ & $\begin{array}{c}-14.8 \pm 18.5 \\
(11)\end{array}$ & $\begin{array}{c}-15.7 \pm 15.7 \\
(11)\end{array}$ & $\begin{array}{c}-16.7 \pm 15.3 \\
(11)\end{array}$ & $\begin{array}{c}-15.5 \pm 14.8 \\
(10)\end{array}$ & $\begin{array}{c}-19.4 \pm 17.9 \\
\text { (7) }\end{array}$ & $\begin{array}{c}-17.7 \pm 16.4 \\
\text { (7) }\end{array}$ \\
\hline $\begin{array}{l}\text { mean } \pm \text { S.D. Tul } \\
\text { a: } P<0.05 \\
\text { b: } P<0.05\end{array}$ & $\begin{array}{l}y \text {-Kramer M } \\
\text { TI (EFV) gr } \\
\text { TI (EFV) gr }\end{array}$ & $\begin{array}{l}\text { ltiple Compa } \\
\text { up at week } 9 \\
\text { up at week } 9\end{array}$ & $\begin{array}{l}\text { son test } \\
\text { vs PI group a } \\
\text { vs ATV/RTV }\end{array}$ & $\begin{array}{l}\text { week } 96 \\
\text { roup at week }\end{array}$ & & & & & \\
\hline
\end{tabular}

\begin{tabular}{|c|c|c|c|c|c|c|c|c|c|}
\hline & Week 4 & Week 12 & Week 24 & Week 36 & Week 48 & Week 60 & Week 72 & Week 84 & Week 96 \\
\hline $\begin{array}{l}\text { naïve } \\
\text { (n) }\end{array}$ & $\begin{array}{c}-2.7 \pm 10.9 \\
(52)\end{array}$ & $\begin{array}{c}-9.0 \pm 11.7 \\
(52)\end{array}$ & $\begin{array}{c}-11.8 \pm 14.8^{*} \\
(52)\end{array}$ & $\begin{array}{c}-12.4 \pm 13.8^{*} \\
(47)\end{array}$ & $\begin{array}{c}-12.4 \pm 15.7^{*} \\
(46)\end{array}$ & $\begin{array}{c}-13.1 \pm 15.3^{*} \\
(43)\end{array}$ & $\begin{array}{c}-12.5 \pm 18.7 \\
(41)\end{array}$ & $\begin{array}{c}-14.2 \pm 18.2^{*} \\
(38)\end{array}$ & $\begin{array}{c}-10.7 \pm 17.3 \\
(37)\end{array}$ \\
\hline $\begin{array}{l}\text { received } \\
\text { (n) }\end{array}$ & $\begin{array}{c}-4.8 \pm 7.0 \\
(14)\end{array}$ & $\begin{array}{c}-6.1 \pm 9.1 \\
(15)\end{array}$ & $\begin{array}{c}-4.6 \pm 12.4 \\
(15)\end{array}$ & $\begin{array}{c}-5.3 \pm 10.0 \\
(13)\end{array}$ & $\begin{array}{c}-5.3 \pm 11.2 \\
(16)\end{array}$ & $\begin{array}{c}-7.0 \pm 13.5 \\
(13)\end{array}$ & $\begin{array}{c}-8.4 \pm 12.3 \\
(14)\end{array}$ & $\begin{array}{c}-4.5 \pm 12.3 \\
(12)\end{array}$ & $\begin{array}{c}-8.4 \pm 13.4 \\
\text { (13) }\end{array}$ \\
\hline
\end{tabular}

\section{Comparison of eGFR in patients receiving cART including TDF}

Changes in the eGFR for each drug combined with TDF in cART at weeks 4, 12, 24, 36, 48, $60,72,84$ and 96 from the start of medication are shown in Table 2. The eGFR in the group treated with PI and ATV/RTV was significantly lower than that in the EFV group week 96. Although there were no significant differences in eGFR between the DRV/RTV and RAL group compared with other groups, the eGFR tended to be decreased.

Comparison of eGFR between patients previously treated and untreated with anti-retroviral drugs

The changes in the eGFR in naïve patients who had not been received anti-retroviral therapy previously and those in patients who had been received such therapy are shown in Table 3. The decrease of the eGFR in the naïve group tended to be greater than that in the previously treated group.

\section{DISCUSSION}

In the present study, it was shown that all cART regimens containing TDF were effective against HIV infection during the 96-week study but they were associated with reduced eGFR noticeable sometime during the period. Although this study did not evaluate concomitant disease or potentially nephrotoxic agents, these findings may indicate a need to select the drugs that are combined with TDF, and that monitoring of renal function is necessary when ATV/RTV, $\mathrm{DRV} / \mathrm{RTV}$ or RAL is used.

TDF is listed in some guidelines as the recommended initial treatment for HIV infection. TDF is relatively safe and used throughout the world. On the other hand, TDF has adverse effects such as renal tubule 
damage, Fanconi's syndrome and nephrogenic diabetes insipidus $(2,3)$. A study that examined the relationship between the serum TDF concentration and renal dysfunction showed that the former was higher in patients who developed renal tubule damage (9). TDF is a drug that is excreted from the kidney by glomerular filtration and tubule secretion. It has been reported that the renal dysfunction caused by TDF is attributable to mitochondrial damage resulting from TDF accumulation in the proximal tubule (10). Multidrug resistance-associated protein (MRP) 4 is one of the ATP-binding cassette transporters expressed in the proximal tubule, and plays a role in tubule secretion $(11,12)$. Although some reports have indicated that MRP2 is expressed in the proximal tubule, and like MRP4 is related to the excretion of TDF (11, $13,14)$, there is no common agreement among researchers. The PI, RTV, exerts inhibitory effects on MRP2 $(15,16)$ and is widely used as a booster for increasing the plasma concentration of other PIs. Kiser et al. have reported that RTV reduces the renal clearance of TDF (14). Furthermore, Goicoechea et al. have demonstrated that the decrease of renal clearance through TDF+boosted-PI is larger than that achieved with TDF+NNRTI (8). In the present study, the decrease of the eGFR achieved with a combination of TDF and PI also tended to be greater than that for the combination of TDF and NNRTI. In the present study, RTV was used as a booster in all patients receiving cART including TDF+PI, and the decrease of eGFR achieved with ATV/RTV or DRV/RTV combined with TDF tended to be especially greater than that for other PI combination regimens. One patient whose medication was changed because of renal dysfunction during the observation period was administered TDF/FTC+ATV/RTV. A decrease of the eGFR with a combination of TDF and ATV/RTV has been reported previously (17), supporting our present findings. Moreover, kidney stones and urolithiasis have been reported as adverse effects of $\operatorname{ATV}(18,19$, $20)$, and this may be related to renal dysfunction.

RAL is the only INSTI that can be used in Japan. RAL is not metabolized by cytochrome P (CYP) 450, but mainly by UDP-glucuronyltransferase 1A1 (21). Thus, drug interactions of RAL may be small in comparison with PI and NNRTI, which is a substrate of CYP and exerts enzyme-inducing and/or -inhibitory effects. Therefore, RAL was expected to be useful for patients who were received multidrug combination therapy. Wennig et al. have reported that there was little difference in the serum TDF concentration between TDF alone and when coadministered with RAL (22). However, in the present study, eGFR after week 12 was decreased in patients receiving the TDF and RAL combination, suggesting the need to be mindful of renal dysfunction in patients receiving this combination. Although the cause of the decrease in eGFR, including details of drug interaction, remains unknown, one possibility is that some patients receiving the TDF and RAL combination had risk factors for renal dysfunction such as diabetes and hypertension, and that concomitant use of other medications might have led to renal dysfunction.

A high serum creatinine level, low body weight, high age, a low CD4 cell count, combined use of drugs with a potential risk of inducing renal dysfunction, high blood pressure and diabetes have been reported as risk factors for renal dysfunction in patients receiving $\operatorname{TDF}(6,7)$. In the present study, the eGFR in naïve patients who had not received anti-retroviral therapy previously tended to be lower than that in patients who had. In the previously treated patients, the CD4 cell count remained high and the plasma HIV-RNA concentration remained low in many cases, and this might have been related to changes in renal function.

Recently, chronic kidney disease (CKD) has been highlighted as one of the complications associated with long-term medication for HIV infection (23). The Euro SIDA group has reported that TDF, indinavir, ATV and LPV/RTV may be CKD-related factors in HIV-infected patients (24). Moreover, Yanagisawa et al. have reported that the CKD rate in HIV-infected Japanese patients is higher than in the general population (25). Therefore, in HIV-infected 
patients who receive cART, laboratory tests of renal function (serum creatinine, eGFR, urine protein and so on) are performed frequently to reveal any signs of dysfunction, in order to avoid progression to CKD.

In the present study, we focused on anti-retroviral drugs used in combination with TDF, including the new drugs, DRV and RAL, and their influences on renal function. However, we used only the eGFR as an index of renal dysfunction and did not examine complications and concomitant medications other than anti-retroviral drugs. Measurement of $\beta_{2}$-microglobulin in urine would be useful for monitoring of renal function, as the renal dysfunction induced by TDF is mainly tubule damage (26). Further detailed studies of the influences of cART on renal function, including urinary $\beta_{2}$-microglobulin, in HIV-infected patients will be necessary. Also, since the number of HIV-infected patients visiting Kitasato University Hospital is generally small, the numbers of patients in the present study groups were consequently low. Moreover, the TDF-treated group was not compared with the non -TDFtreated group (namely patients treated with NRTIs except for TDF). On the basis of our present findings, it is suggested that there is a need to select drugs for use with TDF to avoid adverse effects, and that care is especially necessary when using TDF together with ATV/RTV, DRV/RTV or RAL.

\section{REFERENCES}

1. Cooper DA. Life and death in the cART era. Lancet 2008; 372(9635): 266-267.

2. Karras A, Lafaurie M, Furco A, Bourgarit A, Droz D, Sereni D, Legendre C, Martinez F, Molina JM. Tenofovir-related nephrotoxicity in human immunodeficiency virus-infected patients: three cases of renal failure, Fanconi syndrome, and nephrogenic diabetes insipidus. Clin Infect Dis 2003; 36:1070-1073.

3. Zimmermann AE, Pizzoferrato T, Bedford J, Morris A, Hoffman R, Braden G Tenofovir-associated acute and chronic kidney disease: a case of multiple drug interactions. Clin Infect Dis 2006; 42: 283-290.

4. Gallant JE, Moore RD. Renal function with use of a tenofovir-containing initial antiretroviral regimen. AIDS 2009; 23:197-205.

5. Horberg M, Tang B, Towner W, Silverberg M, Bersoff-Matcha S, Hurley L, Chang J, Blank J, Quesenberry C Jr, Klein D. Impact of tenofovir on renal function in HIV-infected, antiretroviral-naive patients. J Acquir Immune Defic Syndr 2010; 53: 62-69.

6. Nelson MR, Katlama C, Montaner JS, Cooper DA, Gazzard B, Chen SS, Smith S, Bischofberger N, Rooney JF. The safety of tenofovir disoproxil fumarate for the treatment of HIV infection in adults: the first 4 years. AIDS 2007; 21: 1273-1281.

7. Nishijima T, Komatsu H, Gatanaga H, Aoki T, Watanabe K, Kinai E, Honda H, Yazaki H, Tsukada K, Honda M, Teruya K, Kikuchi Y, Oka S. Impact of small body weight on tenofovir-associated renal dysfunction in HIV-infected patients: a retrospective cohort study of Japanese patients. PLos One 2011; 6: e22661.

8. Goicoechea M, Liu S, Best B, Sun S, Jain S, Kemper C, Witt M, Diamond C, Haubrich R, Louie S; California Collaborative Treatment Group $578 \quad$ Team. Greater tenofovir-associated renal function decline with protease inhibitor-based versus nonnucleoside reverse-transcriptase inhibitorbased therapy. J Infect Dis 2008; 197: 102-108.

9. Rodrigues-Novoa S, Labarga P, Davolio A, Barreiro P, Albalate M, Vispo E, Solea C, Siccardi M, Bonora S, Di Perri G, Soriano V. Impairment in kidney tubular function in patients receiving tenofovir is associated with higher tenofovir plasma concentrations. AIDS 2010; 24: 1064-1066.

10. Kohler JJ, Hosseini SH, Hoying-Brandt A, Green E, Johnson DM, Russ R, Tran D, Raper CM, Santoianni R, Lewis W. Tenofovir renal toxicity targets mitochondria of renal proximal tubules. Lab Invest 2009; 89: 513-519.

11. Ray AS, Cihlar T, Robinson KL, Tong L, Vela JE, Fuller MD, Wieman LM, Eisenberg EJ, Rhodes GR. Mechanism of active renal tubular efflux of tenofovir. Antimicrob Agents Chemother 2006; 50: 3297-3304.

12. Kohler JJ, Hosseini SH, Green E, Abuin A, Ludaway T, Russ R, Santoianni R, Lewis W. Tenofovir renal proximal tubular toxicity is regulated by OAT1 and MRP4 transporters. Lab Invest 2011; 91: 852-858.

13. Izzedine H, Holot JS, Villard E, Goyenvalle 
C, Dominguez S, Ghosn J, Valantin MA, Lechat P, Deray G. Association between ABCC2 gene haplotypes and tenofovir-induced proximal tubulopathy. J Infect Dis 2006; 194: 1481-1491.

14. Kiser JJ, Carten ML, Aquilante CL, Anderson PL, Wolfe P, King TM, Delahunty T, Bushman LR, Fletcher CV. The effect of lopinavir/ritonavir on the renal clearance of tenofovir in HIV-infected patients. Clin Pharmacol Ther 2008; 83: 265-272.

15. Miller DS. Nucleoside phosphonate interactions with multiple organic anion transporters in renal proximal tuble. J Pharmacol Exp Ther 2001; 299: 567-574.

16. Izzedine H, Launaly-Vacher V, Deray G. Renal tubular transporters and antiviral drugs: an update. AIDS 2005; 19: 455-462.

17. Young J, Schafer J, Fux CA, Furrer H, Bernasconi E, Vernazza P, Calmy A, Cavassini M, Weber R, Battegay M, Bucher $\mathrm{HC}$, the Swiss HIV Cohort Study. Renal function in patients with HIV starting therapy with tenofovir and either efavirenz, lopinavir or atazanavir. AIDS 2012; 26: 567-575.

18. Pacanowski J, Poirier JM, Petit I, Meynard JL, Girard PM. Atazanavir urinary stones in an HIV-infected patient. AIDS 2006; 20: 2131.

19. Chan-Tack KM, Truffa MM, Struble K, Birnkrant DB. Atazanavir-associated nephrolithiasis: case from the US Food and Drug Administration's adverse event reporting system. AIDS 2007; 21: 1215-1218.

20. Rockwood N, Mandalia S, Bower M, Gazzard B, Nelson M. Ritonavir-boosted atazanavir exposure is associated with an incrased rate of renal stones compared with efavirenz, titonavir-boosted lopinavir and ritonavir-boosted darunavir. AIDS 2011; 25: 1671-1673.
21. Kassahun K, Mclntosh I, Cui D, Hreniuk D, Merschman S, Lasseter K, Azrolan N, Iwamoto M, Wagner JA, Wenning LA. Metabolism and disposition in humans of raltegravir (MK-0518), an anti-AIDS drug targeting the human immunodeficiency virus 1 integrase enzyme. Drug Metab Dispos 2007; 35: 1657-1663.

22. Wennig LA, Friedman EJ, Kost JT, Breidinger SA, Stek JE, Lasseter $\mathrm{KC}$, Gottesiener KM, Chen J, Teppler H, Wagner JA, Stone JA, Iwamoto M. Lack of a significant drug interaction between raltegravir and tenofovir. Antimicrob Agents Chemother 2008; 52: 3253-3258.

23. Menezes AM, Torelly J Jr, Real L, Bay M, Poeta J, Sprinz E. Prevalence and risk factors associated to chronic kidney disease in HIV-infected patients on HAART and undetectable viral load in Brazil. PLoS One 2011; 6: e26042.

24. Mocroft A, Kirk O, Reiss P, De Wit S, Sedlacek D, Beniowski M, Gatell J, Phillips AN, Ledergerber B, Lundgren JD; EuroSIDA Study Grop. Estimated glomerular filtration rate, chronic kidney disease and antiretroviral drug use in HIV-positive patients. AIDS 2010; 24: 1667-1678.

25. Yanagisawa N, Ando M, Ajisawa A, Imamura A, Suganuma A, Tsuchiya K, Nitta K. Clinical characteristics of kidney disease in Japanese HIV-infected patients. Nephron Clin Pract 2011; 118: c285-291.

26. Gatanaga H, Tachikawa N, Kikuchi Y, Teruya K, Genka I, Honda M, Tanuma J, Yazaki H, Ueda A, Kimura S, Oka S. Urinary $\beta_{2}$-microglobulin as a possible sensitive marker for renal injury caused by tenofovir disoproxil fumarate. AIDS Res Hum Retroviruses 2006; 22: 744-748. 